\title{
UJI KINERJA DAN ANALISA BIAYA PENGERINGAN UBI KAYU MENGGUNAKAN PENGERING INFRAMERAH PADA BEBERAPA TINGKAT KAPASITAS BERBEDA
}

\section{PERFORMANCE TESTAND COST ANALYSIS OF CASSAVA DRYING USING INFRARED DRYER UNDER DIFFERENT LEVEL OF CAPACITY}

\section{Dadang Dayat Hidayat, Diang Sagita*), Ari Rahayuningtyas, Novita Dwi Susanti}

Pusat Penelitian Teknologi Tepat Guna - Lembaga Ilmu Pengetahuan Indonesia

Jalan K.S. Tubun No. 5 Subang, Jawa Barat

E-mail: diang.sagita@gmail.com

Diterima : 28-01-2021

Direvisi : 26-03-2021

Disetujui : 23-04-2021

\begin{abstract}
ABSTRAK
Pengeringan ubi kayu merupakan salah satu tahap penting yang dilakukan untuk mengolah ubi kayu menjadi produk tepung.Pengeringan umumnya dilakukan menggunakan sinar matahari maupun secara mekanis menggunakan alat pengering. Namun, penggunaan alat pengering menimbulkan biaya tambahan pada proses produksinya sehingga kinerja teknis dan tekno-ekonominya perlu dianalisis. Penelitian ini bertujuan untuk mengevaluasi kinerja dan menganalisis biaya pengeringan ubi kayu yang dikeringkan dengan menggunakan pengering kabinet dengan pemanas keramik inframerah.Kinerjapengeringan ubi kayu menggunakan alat pengering ini telah berhasil diuji pada beban kosong dan pada tiga variasi kapasitas pengeringan (20, 29 dan $42 \mathrm{~kg}$ ). Karakteristik suhu dan kelembaban pada ruang pengering dapat stabil dan mendekati nilai set point. Peningkatan kapasitas pengeringan tidak menunjukan perbedaan laju pengeringan, akibatnya semakin tinggi kapasitas pengeringan (hingga kapasitas maksimal) semakin tinggi efisiensi pengeringannya, semakin tinggi laju penguapannya dan semakin rendah konsumsi energi spesifiknya. Peningkatan kapasitas juga dapat menurunkan biaya pokok pengeringan hingga mencapai Rp.1,056,00 per kg ubi kayu basah pada kapasitas $42 \mathrm{~kg} /$ batch. Penggunaan alat pengering berbantu pemanas inframerah ini sangat ditekankan untuk dioperasikan pada kapasitas maksimal agar dapat menekan biaya operasional yang berdampak pada menurunya biaya pokok pengeringan.
\end{abstract}

Kata Kunci: analisis biaya, kinerja, pengering inframerah, pengeringan, ubi kayu

\begin{abstract}
Cassava drying is one of the essential steps taken to process cassava into flour products. Drying is generally carried out using sunlight or mechanically using a dryer. However, the use of a dryer incurs additional costs in the production process so that technical and techno-economic performance analysis is essential. This study aims to evaluate the performance and to analyze the cost of cassava drying, which is dried using an infrared ceramic heater assisted cabinet dryer. The drying performance of cassava using this cabinet dryer has been successfully tested at empty load and at three variations of drying capacity $(20,29$, and $42 \mathrm{~kg}$ ). The temperature and humidity characteristics of the drying chamber can be stable and approach the setpoint values. The increase in drying capacity does not show a difference in drying rates, consequently the higher the drying capacity (up to the maximum capacity) the higher the drying efficiency, the higher the evaporation rate, and the lower the specific energy consumption. Increased capacity can also reduce the cost of drying up to Rp.1,056.00 per $\mathrm{kg}$ of wet cassava at a capacity of $42 \mathrm{~kg} /$ batch. The use of infrared heating assisted dryers is emphasized
\end{abstract}


to be operated at maximum capacity in order to reduce operational costs which have an impact on reducing the cost of drying.

Keywords: cost analysis, performance, infrared dryer, drying, cassava

\section{PENDAHULUAN}

bi kayu atau Singkong (Manihot esculenta) merupakan salah satu sumber karbohidrat lokal Indonesia yang menduduki urutan ketiga terbesar setelah padi dan jagung(Zarkasie et al., 2017). Sebagai salah satu produk diversifikasi pangan yang potensial, ubi kayu memiliki beberapa kelemahan antara lain mudah rusak dan tidak tahan lama (Sagala dan Suwarto, 2017). Ubi kayu segar dapat bertahan dalam penyimpanan selama kurang lebih2-5 hari, dan jika lebih dari ituakan berdampak pada warna umbinya menjadi coklat kebiruan. Oleh karena itu, setelah dipanen ubi kayuharus segera dikonsumsi atau diproses lebih lanjut.Terdapat beberapa upaya untuk mempertahankan daya simpan ubi kayu, sebagai contoh yaitumengolahnya menjadi produk lain seperti tape, keripik, gaplek, tepung tapioka, dan tepung mocaf.

Saat ini, pemerintah Indonesia mendorong ubi kayu agar dapat menjadi produk substitusi tepung terigu, bahan baku industri pangan, termasuk roti dan kue, sehingga dapat meningkatkan kandungan bahan lokal dan meminimalkan bahan baku impor (Argoet al., 2018). Dalam kaitannya dengan tahapan pengolahan ubi kayu menjadi produk kering seperti tepung tapioka, mocaf dan gaplek, pengeringan menjadi salah satu tahapan yang sangat penting.Pengeringan dapat dilakukan secara konvensional menggunakan sinar matahari atau secara mekanis menggunakan alat pengering.Pengeringan secara mekanis menggunakan alat pengering sangat dibutuhkan sebagai solusi cuaca yang tidak menentu, musim hujan, atau untuk menjaga kontinuitas produksi.

Pengering tipe kabinet atau rakmerupakan jenis pengering konveksi yang paling sederhana (Grabowski et al., 2003), dan cocok untuk kegiatan produksi skala kecil dan menengah (Driscoll, 2008). Pengering kabinet dapat mengeringkan hampir semua bahan yang dapat ditempatkan di atas nampan/tray(Sokhansanj dan Jayas, 2007), membutuhkan input modal yang rendah dan biaya perawatan yang rendah(Jayaraman dan Gupta, 2007). Beberapa penerapan pengering tipe rak/kabinet sudah banyak digunakan bahkan untuk produk pangan khas Indonesia seperti kerupuk rambak (Sirait, 2013) dan rengginang (Sirait, 2012).

Sistem pemanas untuk alat pengering tersedia cukup beragam, dan saat ini penggunaan teknologi pemanas inframerah merupakan salah satu yang cukup banyak digunakan. Teknologi Inframerah sangat hemat energi dan ramah lingkungan dibandingkan dengan pemanas konvensional(Aboud et al., 2019). Selain itu, dicirikan juga dengan homogenitas pemanasan dan laju perpindahan panas yang tinggi, waktu pemanasan yang rendah, konsumsi energi yang rendah, kualitas produk lebih baik, dan keamanan pangan lebih terjaga (Aboud et al., 2019). Dengan keunggulan-keunggulannya, maka teknologi pemanas inframerah telah banyak digunakan sebagai penghangat kandang (Juariah, 2013), pemanggang/penyangrai kopi(Hidayat et al., 2020) dan juga pengering untuk produk irisan singkong (Rahayuningtyas dan Afifah, 2016).

Untuk mengetahui efektifitas dan efisiensi pengeringan dari suatu alat pengering, diperlukan analisis terhadap kinerja pengeringannya.Beberapa penelitian tentang kinerja alat pengering telah dilakukan antara lain pada pengeringan gabah menggunakan pengering tipe rak menggunakan sumber energi surya dan biomassa(Panggabean et al., 2017), pengeringan tepung ubi kayu menggunakan pengering tipe rak dengan sumber panas matahari(Suherman et al., 2018), pengembangan model prediksi pengeringan berdasarkan 
variasi ketebalan irisan wortel menggunakan pengering rak (Saputra et al., 2020), pemodelan kinetika pengeringan menggunakan pengering inframerah(Afifah et al., 2017), dan pengeringan irisan singkong menggunakan pengering inframerah(Afifah et al., 2015). Pada penelitian sebelumnya pengujian dilakukan pada kapasitas rendah $(6 \mathrm{~kg})$ dan belum memperhitungkan efisiensi pengeringan. Penelitian ini bertujuanuntuk melakukan uji kinerja alat pengering inframerah menggunakan bahan ubi kayu pada berbagai tingkat kapasitas, menganalisis efisiensi pengeringan dan menganalisis biaya pengeringannya sehingga diperoleh besarnya biaya pengeringan yang paling optimum menggunakan alat pengering jenis ini.

\section{BAHAN DAN METODE}

\section{Alat dan Bahan}

Bahan yang digunakan adalah ubi kayu (Manihot esculenta) yang telah dikupas dan diiris dengan ketebalan 2-3 mm. Kadar air awal ubi kayu rata-rata adalah $71,40 \% \mathrm{bb}$. Alat yang digunakan adalah satu unit alat pengering tipe kabinet(dimensi: $2 \times 2 \times 2 \mathrm{~m}$ ) dengan pemanas keramik inframerah (merk Gasolec) berbahan bakar LPG, loyang berpori dengan ukuran $65 \times 40 \mathrm{~cm}$, timbangan digital, halogen moisture analyzer (Mettler Toledo) dengan tingkat ketelitian 0,01\%. Deskripsi alat pengering yang digunakan disajikan pada Gambar 1 .

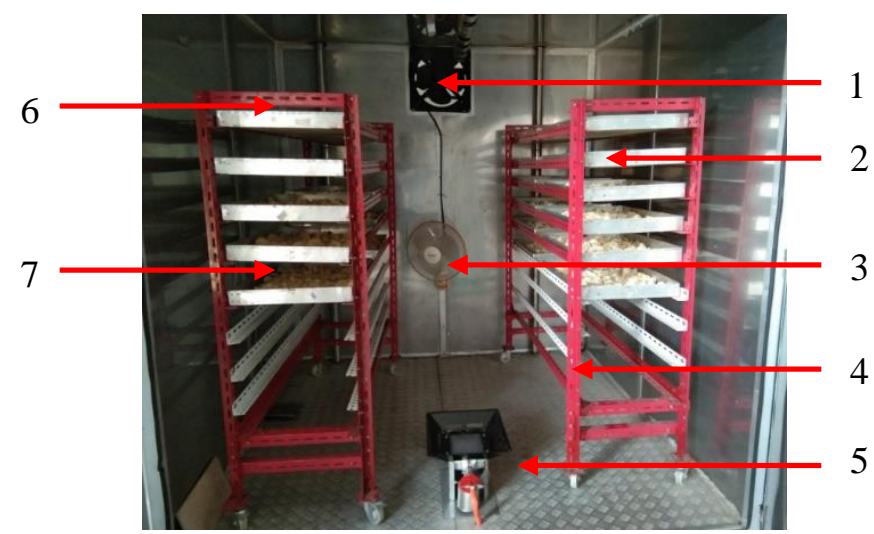

Gambar 1. Alat pengering inframerah: (1) exhaust fan, (2) loyang pengering, (3) Kipas sirkulasi, (4) rak pengering, (5) pemanas keramik inframerah berbahan bakar gas LPG, (6) posisi sensor DHT22 di bagian atas, (7) posisi sensor DHT22 di posisi bagian bawah

\section{Metode}

Metode penelitian yang digunakan adalah metode penelitian ekperimental dan deskritif dengan 3 jenis perlakuan kapasitaspengeringan yaitu $20 \mathrm{~kg}, 29 \mathrm{~kg}$ dan $42 \mathrm{~kg}$. Irisan singkong diletakan pada loyang dengan massa per loyang adalah $1 \mathrm{~kg}$ irisan singkong. Pengeringan dilakukan selama 8 jam.Parameter yang diukur untuk menentukan kinerja alat adalah suhu dan kelembaban relatif di ruang pengering, waktu pengeringan, kadar air, laju penguapan air, dan kebutuhan energi untuk pengeringan. Selain itu pada penelitian ini juga dilakukan analisis biaya pengeringan menggunakan alat pengering ini.Analisis biaya dihitung berdasarkan parameter kinerja alat yang telah diamati.

\section{a. Pengamatan suhu dan kelembaban}

Pengukuran suhu dan kelembaban di dalam ruang pengering dilakukan menggunakan sensor DHT22 yang telah dikalibrasi dan diintegrasikan dengan mikrokontroller Arduino Mega. Sensor DHT22 memiliki tingkat akurasi pembacaan suhu sebesar $0,5{ }^{\circ} \mathrm{C}$ dan kelembaban 2\% (Ada, 2020). Terdapat 2 buah sensor yang diletakan di dalam ruang 
pengering yaitu pada posisiatas (sejajar loyang paling atas) dan posisi bawah (sejajar loyang paling bawah). Data suhu dan kelembaban dapat diamati melalui LCD display (Gambar 2) dan direkam secara otomatis selama proses pengeringan dengan interval 5 detik. Data disimpan di dalam kartu memori dan diambil setelah proses pengeringan selesai.

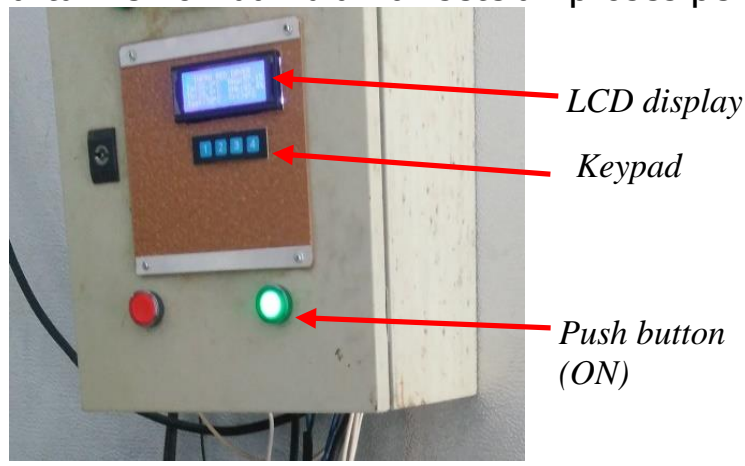

Gambar 2. Panel box kontrol untuk monitoring suhu dan kelembaban di dalam ruang pengering

\section{b. Pengukuran kadar air}

Pengukuran kadar air dilakukan setiap 30 menit untuk 3 jam pertama, dan selanjutnya diukur pada tiap 60 menit. Sampelyang diambil dengan berat 0,8 gkemudian dimasukan ke dalam alat halogen moisture analyzer merk Mettler Toledodengan tingkat ketelitian 0,01\% untuk mengetahui nilai kadar airnya (\%bb).

\section{c. Perhitungan waktu dan laju penguapan air}

Waktu penguapan air dihitung sejak alat pengering mulai dinyalakan hingga alat pengering dimatikan. Sementara itu, laju penguapan air dihitung berdasarkan pendekatan nilai akhir kadar air menggunakan Persamaan 1-4. Persamaan ini merupakan turunan dari rumus perhitungan laju penguapan air pada umumnya dengan hanya memperhitungkan massa awal, kadar air awal dan kadar air akhir.

$$
\begin{aligned}
& M_{\text {solid }}=M_{\text {awal }}-\left(M_{\text {awal }} \times K A_{\text {awal }}\right) \\
& M_{\text {akhir }}=\frac{M_{\text {solid }}}{1-K A_{\text {akhir }}} \\
& M_{\text {uap }}=M_{\text {awal }}-M_{\text {akhir }} \\
& L_{\text {uap }}=\frac{M_{\text {uap }}}{t}
\end{aligned}
$$

Dimana:

$$
\begin{array}{ll}
L_{\text {uap }} & : \text { laju penguapan air }\left(\mathrm{kg} \mathrm{H} \mathrm{H}_{2} \mathrm{O} / \mathrm{jam}\right) \\
M_{\text {uap }} & : \text { massa air yang diuapkan }(\mathrm{kg}) \\
M_{\text {awal }} & : \text { massa awal ubi kayu yang dikeringkan }(\mathrm{kg}) \\
K A_{\text {Awal }} & : \text { kadar air awal ubi kayu }(\% \mathrm{bb}) \\
M_{\text {solid }} & : \text { massa padatan pada ubi kayu }(\mathrm{kg}) \\
K A_{a k h i r} & : \text { kadar air akhir ubi kayu }(\% \mathrm{bb}) \\
M_{\text {akhir }} & : \text { perkiraan massa akhir ubi kayu setelah dikeringkan }(\mathrm{kg}) \\
t & : \text { waktu pengeringan (jam) }
\end{array}
$$

\section{d. Analisis efisiensi pengeringan}

Efisiensi energi dihitung berdasarkan energi input dan energi output. Energi input dihitung berdasarkan persamaan 5(Putra et al., 2018).

$$
E_{i n}=K_{b b} \times C_{b b}+\frac{\left(P_{f a n}+P_{e f}+P_{s m}\right) \times t}{1000}
$$

Dimana: 


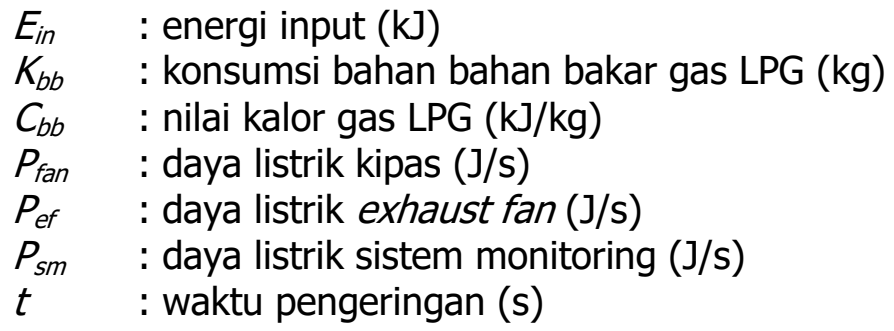

Selanjutnya energi output dalam hal ini adalah energi yang termanfaatkan untuk menguapkan air dari bahan dihitung menggunakan Persamaan 6(Putra et al., 2018).

$$
\begin{aligned}
& E_{\text {out }}=Q_{1}+Q_{2} \\
& Q_{1}=E \times H_{l} \\
& Q_{2}=m \times c_{p} \times \Delta T
\end{aligned}
$$

Dimana:

$E_{\text {out }} \quad$ : energi output yang digunakan untuk pengeringan $(\mathrm{kJ})$

$Q_{1} \quad$ : energi untuk menguapkan air $(\mathrm{kJ})$

$E \quad$ : jumlah air yang diuapkan $\left(\mathrm{kg} \mathrm{H}_{2} \mathrm{O}\right)$

$\mathrm{H}_{\text {I }}$ : panas laten penguapan air $\left(\mathrm{kJ} / \mathrm{kg} \mathrm{H} \mathrm{H}_{2} \mathrm{O}\right)$

$m \quad$ : massa bahan yang dikeringkan $(\mathrm{kg})$

$c_{p} \quad$ : panas jenis bahan yang dikeringkan $\left(\mathrm{kJ} / \mathrm{kg}^{\circ} \mathrm{C}\right)$

$\Delta T \quad$ : selisih antara suhu bahan pada saat awal dan saat dikeringkan (s)

Efisiensi energi pengeringan dan besarnya konsumsi energi spesifik dihitung menggunakan Persamaan 9 dan 10(Putra et al., 2018).

$$
\begin{aligned}
& \eta=\frac{\mathrm{E}_{\text {in }}}{\mathrm{E}_{\text {out }}} \times 100 \% \\
& S E C=\frac{\mathrm{E}_{\text {in }}}{\mathrm{k}_{p}}
\end{aligned}
$$

Dimana:

$\eta \quad$ : efisiensi pengeringan (\%)

SEC : konsumsi energi spesifik $(\mathrm{kJ} / \mathrm{kg})$

$k_{p} \quad$ : kapasitas pengeringan $(\mathrm{kg})$

\section{e. Analisis biaya pengeringan}

Analisis biaya pengeringan dihitung berdasarkan biaya tetap dan biaya tidak tetap dari penggunaan alat pengering inframerah.Biaya tetap $\left(B_{T}\right)$ hanya diperhitungkan dari biaya penyusutan atau depresiasi alat pengering $(D)$. Sementara biaya tidak tetap $\left(B_{T T}\right)$ diperhitungkan dari beberapa hal yaitu: 1$)$ biaya konsumsi bahan bakar gas $\left.\left(B_{k b b}\right) ; 2\right)$ biaya listrik $\left(B_{1}\right) ; 3$ ) biaya perawatan $\left(B_{p 1}\right)$; dan 4 ) biaya perbaikan $\left(B_{p 2}\right)$.

Besarnya biaya pokok pengeringan $\left(B_{p p}\right)$ dihitung menggunakan Persamaan 11.Biaya tetap ( $\mathrm{Rp} / \mathrm{hari})$, biaya tidak tetap ( $\mathrm{Rp} / \mathrm{hari}$ ) dan biaya penyusutan (Rp/hari) masing-masing dihitung menggunakan Persamaan 12, 13 dan 14. Dimana, $k_{p}$ adalah kapasitas pengeringan $(\mathrm{kg} /$ hari), $H$ adalah harga awal alat pengering (Rp), $S$ adalah harga sisa alat pengering (Rp) dan $t_{e}$ adalah umur ekonomis alat (tahun).

$$
\begin{aligned}
& B_{p p}=\frac{B_{T}+B_{T T}}{k_{p}} \\
& B_{T}=D \\
& B_{T T}=B_{k b b}+B_{l}+B_{p 1}+B_{p 2}
\end{aligned}
$$




$$
D=\frac{H-S}{t_{e} \times 365}
$$

\section{HASIL DAN PEMBAHSAN}

\section{Karakteristik Suhu dan Kelembaban}

Karakteristik suhu dan kelembaban pada proses pengeringan menggunakan alat pengering kabinet dengan pemanas keramik inframerah telah diperoleh berdasarkan pengujian. Suhu dan kelembaban diuji pada kondisi tanpa beban (beban kosong) dan dengan beban. Profil dari suhu dan kelembaban pada kondisi beban kosong disajikan pada Gambar 3 dan kondisi dengan beban disajikan pada Gambar 4.

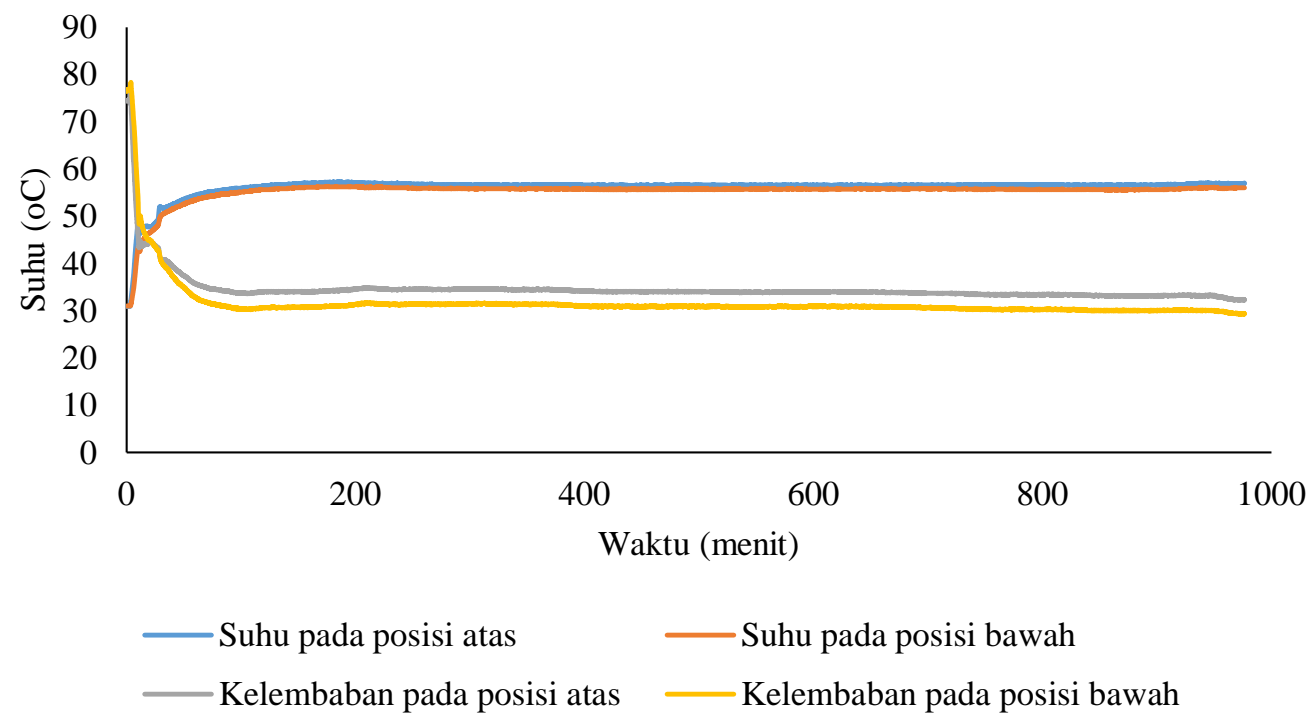

Gambar 3. Karakteristik suhu dan kelembaban di ruang pengering pada kondisi beban kosong

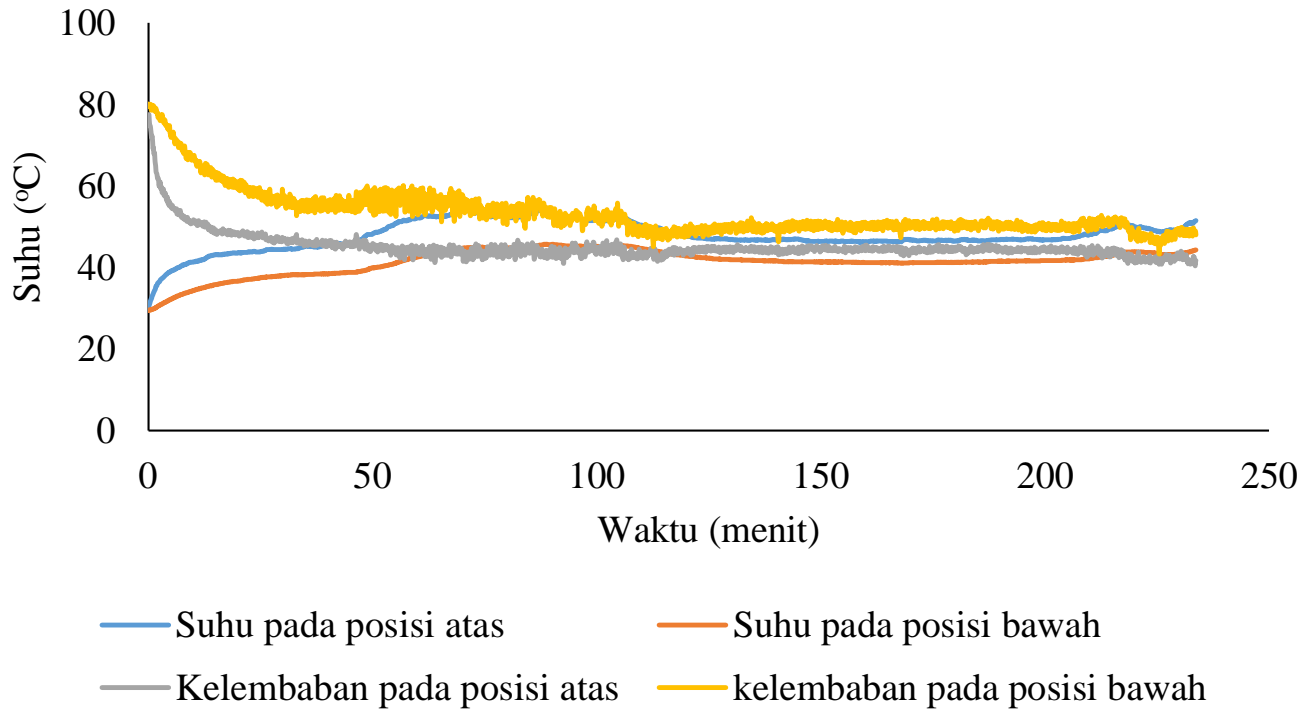

Gambar 4. Karakteristik suhu dan kelembaban di ruang pengering pada kondisi dengan beban

Pada Gambar 3 terlihat bahwa suhu di dalam ruang pengering mengalami kenaikan pada 100 menit pertama hingga mencapai kondisi tunak (steady state) pada suhu rata-rata 
$56,64{ }^{\circ} \mathrm{C}$ (atas) dan $55,76{ }^{\circ} \mathrm{C}$ (bawah) yang mana set point suhu pada pengujian ini adalah $55^{\circ} \mathrm{C}$. Sementara kondisi kelembaban terjadi sebaliknya yaitu penurunan hingga mencapai kondisi tunak pada nilai kelembaban 33,89\% (atas) dan 30,76\% (bawah). Kelembaban di dalam ruang pengering turun karena tidak adanya bahan yang dipanaskan sehingga tidak ada pasokan uap air ke udara yang akhirnya membuat udara di dalam ruangan menjadi kering dan kelambabannya rendah. Hasil evaluasi juga menunjukan sebaran suhu dan kelembaban yang relatif seragam.

Gambar 4 menunjukan profil suhu dan kelembaban pada ruang pengering dengan beban berupa irisan ubi kayu. Pada pengujian ini, set point suhu diatur pada $50{ }^{\circ} \mathrm{C}$ karena merupakan kondisi paling optimum untuk pengeringan. Kondisi kenaikan suhu dan penurunan kelembaban terjadi sebagaimana pada kondisi tanpa beban, namun kurvanya terlihat tidak begitu halus karena adanya bahan yang dipanaskan di dalam ruangan. Terlihat bahwa kelembabannya berada pada kondisi stabil setelah 125 menit dengan nilai antara rata-rata $43,97 \%$ (atas) sampai $50,04 \%$ (bawah). Nilai ini lebih tinggi dibanding pengujian tanpa beban karena pada pengujian dengan beban irisan ubi kayu, terjadi difusi uap air dari ubi kayu ke udara yang menyebabkan kandungan air di udara menjadi bertambah. Kelembaban dapat bertahan pada nilai $<50 \%$ (tidak naik terus menerus) karena adanya sistem sirkulasi udara ke lingkungan. Ketika kelembaban udara di dalam lebih besar dari $50 \%$ maka exhaust fan akan menyala dan mensirkulasikan udara dari luar ke dalam dan dari dalam ke luar.

\section{Kadar Air Selama Pengeringan}

Pengamatan kadar air selama pengeringan dilakukan pada 3 percobaan yaitu kapasitas pengeringan $20 \mathrm{~kg}, 29 \mathrm{~kg}$, dan $42 \mathrm{~kg}$ (maksimal) dimana setiap loyang diisi dengan massa singkong sebanyak $1 \mathrm{~kg}$. Perubahan kadar air selama pengeringan pada ketiga perlakuan disajikan pada Gambar 5. Berdasarkan kurva grafik tersebut, dapat diketahui bahwa laju penurunan kadar air ketiga perlakuan menunjukkan model yang sama dengan model logaritmik Henderson-Pabis dengan nilai koefisien determinasi $\left(R^{2}\right)$ sebesar 0,978 pada kapasitas $20 \mathrm{~kg}$, 0,944 pada kapasitas $29 \mathrm{~kg}$ dan 0,974 pada kapasitas $42 \mathrm{~kg}$. Sementara itu konstanta laju penurunan kadar air masing-masing dari kapasitas 20, 29 dan $42 \mathrm{~kg}$ adalah $\mathrm{e}^{(-0,0033 \mathrm{x})}, \mathrm{e}^{(-0,0035 \mathrm{x})}$ dan $\mathrm{e}^{(-0,0039 \mathrm{x})}$. Dengan demikian laju pengeringan ketiga perlakuan tidak menunjukkan perbedaan yang signifikan berdasarkan model matematikanya dan juga kurva yang terlihat hampir berhimpit antara ketiganya. 


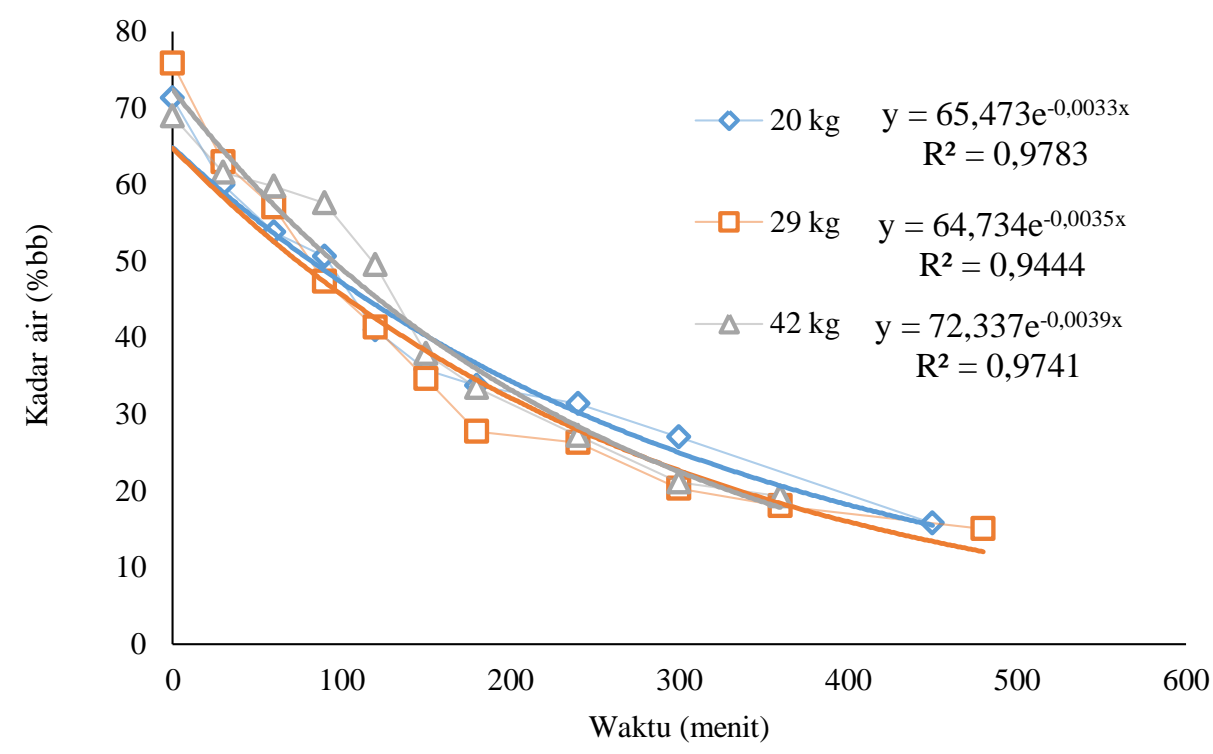

Gambar 5. Perubahan kadar air selama pengeringan pada setiap kapasitas

\section{Laju Penguapan Air}

Laju pengupan air pada ubi kayu telah dihitung berdasarkan pendekatan nilai kadar air akhir-nya. Besarnya laju penguapan air selama proses pengeringan pada 6-8 jam pengeringan pada setiap perlakuan disajikan pada Tabel 1.

Berdasarkan Tabel 1, dapat diketahui bahwa peningkatan kapasitas pengeringan, meningkatkan laju penguapan air dari bahan yang dikeringkan. Hal ini terjadi karena semakin banyak bahan yang dipanaskan maka potensi air yang diupkan akan semakin banyak per satuan waktu yang sama.

Tabel 1.Laju penguapan air pada ubi kayu pada tiga perlakuan kapasitas

\begin{tabular}{lccc}
\hline \multirow{2}{*}{ Parameter } & \multicolumn{3}{c}{ Kapasitas $(\mathrm{kg})$} \\
\cline { 2 - 4 } & 20 & 29 & 42 \\
\hline Waktu (t) & 7,5 & 8,0 & 6,0 \\
$\mathrm{KA}_{\text {Awal }}(\% \mathrm{bb})$ & 71,28 & 75,81 & 68,92 \\
$\mathrm{KA}_{\text {Akhi }} \mathrm{r}(\% \mathrm{bb})$ & 15,72 & 15,03 & 19,31 \\
$\mathrm{M}_{\text {solid }}(\mathrm{kg})$ & 5,74 & 7,02 & 13,05 \\
$\mathrm{M}_{\text {akhir }}(\mathrm{kg})$ & 6,82 & 8,26 & 16,18 \\
$\mathrm{M}_{\text {uap }}(\mathrm{kg})$ & 13,18 & 20,74 & 25,82 \\
$\mathrm{~L}_{\text {uap }}(\mathrm{kg} / \mathrm{jam})$ & 1,76 & 2,59 & 4,30 \\
\hline
\end{tabular}

\section{Efisiensi Pengeringan}

Hasil perhitungan efisiensi pengeringan disajikan pada Tabel 2. Data-data untuk analisis diperoleh dari spesifikasi alat yaitu daya listrik exhaust fan $\left(P_{e f}\right)$ sebesar 200 watt, daya listrik kipas $\left(P_{\text {fan }}\right)$ sebesar 400 watt dan daya listrik sistem monitoring $\left(P_{s m}\right)$ sebesar 15 watt. Sementara beberapa data parameter seperti panas spesifik bahan $\left(C_{p}\right)$, panas laten penguapan $\left(H_{1}\right)$ dan nilai kalor bahan bakar $\left(C_{b b}\right)$ diperoleh dari literatur dengan nilai masing-

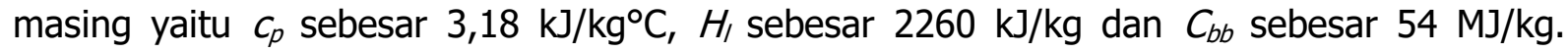


Konsumsi bahan bakar $\left(K_{b b}\right)$ rata-rata untuk ketiga perlakuan hampir sama yaitu 0,28 $\mathrm{kg} / \mathrm{jam}, \Delta \mathrm{T}$ sebesar $21,5^{\circ} \mathrm{C}$ dan waktu pengamatan adalah 6-8 jam.

Tabel 2.Efisiensi pengeringan menggunakan pengering inframerah pada beberapa tingkat kapasitas

\begin{tabular}{lrrr}
\hline \multirow{2}{*}{ Parameter } & \multicolumn{3}{c}{ Kapasitas $(\mathrm{kg})$} \\
\cline { 2 - 4 } & \multicolumn{1}{c}{20} & \multicolumn{1}{c}{29} \\
\hline $\mathrm{t}$ (jam) & 7,5 & 8,0 & 6,0 \\
$\mathrm{KA}_{\text {Akhi }}(\% \mathrm{obb})$ & 15,72 & 15,03 & 19,31 \\
Ei (kJ) & 141220,4 & 125712,0 & 109011,3 \\
$\mathrm{M}_{\text {uap }}\left(\mathrm{kg} \mathrm{H}_{2} \mathrm{O}\right)$ & 13,2 & 20,7 & 25,8 \\
$\mathrm{E}_{\text {out }}(\mathrm{kJ})$ & 31164,6 & 48864,2 & 61230,5 \\
$\mathrm{E}_{\text {ff }}(\%)$ & 22,1 & 38,9 & 56,2 \\
SEC $\left(\mathrm{kJ} \mathrm{kg}^{-1}\right.$ jam $\left.^{-1}\right)$ & 941,5 & 541,9 & 432,6 \\
\hline
\end{tabular}

Berdasarkan hasil analisis, diketahui bahwa semakin besar kapasitas pengeringan, maka semakin besar efisiensi pengeringannya. Hal ini karena di dalam ruang pengering terjadi penyebaran suhu yang sama selama proses pengeringan dan seperti yang telah diketahui bahwa laju penurunan kadar air setiap perlakuan hampir sama sehingga laju penguapan airnya akan berbanding lurus dengan kapasitas bahan yang dikeringkan. Semakin besar kapasitas maka laju air yang diuapkan dari bahan semakin besar sehinga efisiensinya semakin besar dan konsumsi energi spesifiknya semakin kecil. Namun dengan catatan bahwa ini berlaku hingga kapasitas maksimal dari alat pengering ini yaitu antara 40-50 kg (dengan kapasitas $1 \mathrm{~kg}$ per loyang).

\section{Biaya Pengeringan Ubi Kayu Menggunakan Pengering Inframerah}

Biaya pokok pengeringan ubi kayu menggunakan pengering inframerah disajikan pada Tabel 3. Perhitungan ini didasarkan pada beberapa komponen biaya seperti harga alat pengering yang diperkirakan Rp.30,000,000,00 dan nilai akhirnya Rp.2,000,000,00 setelah 20 tahun umur ekonomisnya, harga bahan bakar gas adalah Rp.25,000,00 per $3 \mathrm{~kg}$, harga listrik Rp.1445 per kWh. Alat pengering diperhitungkan bekerja setiap hari selama setahun dengan waktu pengeringan 8 jam per hari dimana kadar air ubi kayu dapat turun hingga 13-15\%.

Berdasarkan Tabel 3, peningkatan kapasitas pengeringan dapat menurunkan biaya pokok pengeringan hingga Rp.1,056,00/kg ubi kayu basah. Hal ini karena input biaya yang dikenakan pada semua perlakuan sama, baik pada biaya tetap (depresiasi) maupun pada biaya tidak tetapnya (biaya bahan bakar, biaya listrik, perawatan dan perbaikan) sehingga semakin besar kapasitasnya (hingga $42 \mathrm{~kg}$ ) maka biaya yang dikeluarkan per satuan massanya menjadi semakin rendah.

Tabel 3. Perbandingan biaya pokok pengeringan

\begin{tabular}{lrrr}
\hline \multirow{2}{*}{ Parameter } & \multicolumn{3}{c}{ Kapasitas $(\mathrm{kg})$} \\
\cline { 2 - 4 } & \multicolumn{2}{c}{20} & \multicolumn{1}{c}{42} \\
\hline Harga awal alat & Rp.30,000,000,00 & Rp.30,000,000,00 & Rp.30,000,000,00 \\
Harga sisa alat & Rp.2,000,000,00 & Rp.2,000,000,00 & Rp.2,000,000,00 \\
Umur ekonomis & 20 & 20 & 20 \\
Biaya tetap (Rp/tahun) & Rp.1,400,000,00 & Rp.1,400,000,00 & Rp.1,400,000,00 \\
Biaya bahan bakar (Rp/hari) & Rp.20,513,00 & Rp. $16,667,00$ & Rp.19,697,00
\end{tabular}




\begin{tabular}{lrrr} 
Biaya listrik (Rp/hari) & Rp.7,109,00 & Rp.7,109,00 & Rp.7,109,00 \\
Biaya perawatan (Rp/hari) & Rp.8,219,00 & Rp.8,219,00 & Rp.8,219,00 \\
Biaya Perbaikan (Rp/hari) & Rp.5,479,00 & Rp.5,479,00 & Rp.5,479,00 \\
Biaya Total (Rp/hari) & Rp.45,156,00 & Rp.41,310,00 & Rp.44,341,00 \\
Biaya pokok produksi (Rp/kg) & Rp.2,258,00 & Rp.1,424,00 & Rp.1,056,00 \\
\hline
\end{tabular}

\section{KESIMPULAN}

Kinerja pengeringan ubi kayu menggunakan alat pengering kabinet dengan pemanas keramik inframerah telah berhasil diuji pada beban kosong dan pada tiga variasi kapasitas pengeringan. Karakteristik suhu dan kelembaban pada ruang pengering dapat stabil sesuai set point suhu dan kelembaban. Kadar air singkong sebesar $13-15 \%$ dapat dicapai pada pengeringan selama sekitar 8 jam untuk semua perlakuan. Peningkatan kapasitas pengeringan tidak menunjukan perbedaan laju pengeringan, akibatnya semakin tinggi kapasitas pengeringan (hingga kapasitas maksimum) semakin tinggi efisiensi pengeringannya, semakin tinggi laju penguapannya dan semakin rendah konsumsi energi spesifiknya. Peningkatan kapasitas juga dapat menurunkan biaya pokok pengeringan hingga mencapai Rp.1,056,00 per kg ubi kayu basah pada kapasitas $42 \mathrm{~kg} /$ batch.

Penggunaan alat pengering berbantu pemanas inframerah ini sangat ditekankan untuk dioperasikan pada kapasitas maksimal (42 kg) dan tidak direkomendasikanjika dioperasikan pada kapasitas kecil karena semakin besar kapasitas (hingga kapasitas maksimal) dapat menekan biaya operasional yang berdampak pada menurunya biaya pokok pengeringan.

\section{UCAPAN TERIMAKASIH}

Penulis mengucapkan terimakasih kepada Pusat Penelitian Teknologi tepat Guna LIPI, para teknisi litkayasa (Pak Teguh, Pak Iman, Pak Dadang, Pak Taufik, Pak Suhaya, Pak Rony, Pak Edi) dan seluruh pihak yang telah membantu dan mendukung kegiatan penelitian ini.

\section{DAFTAR PUSTAKA}

Aboud, S. A., A. B. Altemimi, A. R. S. Al-hiiphy, L. Yi-chen, danF. Cacciola. 2019. A Comprehensive Review on Infrared Heating. Molecules, 2: 1-20.

Ada, Lady. 2020. DHT11, DHT22 and AM2302 Sensors. Adafruit Learning System. https://cdn-learn.adafruit.com/downloads/pdf/dht.pdf. 27 Januari 2021.

Afifah, N., A. Rahayuningtyas, A. Haryanto, dan S. I. Kuala. 2015. Pengeringan Lapisan-Tipis Irisan Singkong Menggunakan Pengering Infrared. Pangan, 24(3): 217-224.

Afifah, N., A. Rahayuningtyas, danS. I. Kuala. 2017. Pemodelan Kinetika Pengeringan Beberapa Komoditas Pertanian Menggunakan Pengering Inframerah. Agritech, 37(2): 220.

Argo, B. D., S. Sandra, dan Ubaidillah. 2018. Mathematical modeling on the thin layer drying kinetics of cassava chips in a multipurpose convective-type tray dryer heated by a gas burner. Journal of Mechanical Science and Technology, 32(7): 3427-3435.

Driscoll, R. 2008. Food dehydration. In J. Smith dan Y. Hui (Eds.), Food processing: principles and applications. Blackwell Publishing.

Grabowski, S., M. Marcotte, danH. Ramaswamy. 2003. Drying of fruits, vegetables, and spices. In A. Chakraverty, A. Mujumdar, G. Raghavan, dan Ramaswamy (Eds.), Handbook of postharvest technology: cereals, fruits, vegetables, tea, and spices (pp. 653-695). Marcel Dekker Inc. 
Hidayat, D. D., A. Sudaryanto, Y. R. Kurniawan, A. Indriati, danD. Sagita. 2020. Development and Evaluation of Drum Coffee Roasting Machine for Small-Scale Enterprises. INMATEH Agricultural Engineering, 60(1): 79-88.

Jayaraman, K., dan D. Gupta. 2007. Drying of fruits and vegetables. In A. Mujundar (Ed.), Handbook of industrial drying (3rd ed., pp. 606-633). Taylor dan Francis.

Juariah, E. 2013. Dasar-Dasar Peternakan. Kementrian Pendidikan dan Kebudayaan.

Panggabean, T., A. N. Triana, dan A. Hayati. 2017. Kinerja Pengeringan Gabah Menggunakan Alat Pengering Tipe Rak dengan Energi Surya, Biomassa, dan Kombinasi. Agritech, 37(2): 229.

Putra, M. A., S. Asmara, C. Sugianti, dan Tamrin. 2018. Uji kinerja alat pengering silinder vertikal pada proses pengeringan jagung (zea mays ssp. mays). Jurnal Teknik Pertanian Lampung, 7(2): 88-96.

Rahayuningtyas, A., danN. Afifah. 2016. Rancang Bangun, Uji Performa dan Analisa Biaya Pengeringan Irisan Singkong Menggunakan Pengering Inframerah. Jurnal Pangan, 25(1): 33-42.

Sagala, E., dan Suwarto. 2017. Manajemen Panen dan Pasca Panen Ubi Kayu (Manihot esculenta Crantz) untuk Bahan Baku Industri Tapioka di Lampung. Buletin Agrohorti, 5(3): 400-409.

Saputra, T. W., S. Waluyo, A. Septiawan., dan S. Ristiyana. 2020. Pengembangan model prediksi laju pengeringan pada irisan wortel (Daucus carota) berbasis regresi linier berganda (RLB) dan jaringan syaraf tiruan (JST). Jurnal IImiah Rekayasa Pertanian Dan Biosistem, 8(2): 209-218.

Sirait, J. 2012. Pembuatan alat pengering kerupuk rengginang dengan kapasitas $7 \mathrm{~kg}$ di Samarinda. Jurnal Riset Teknologi Industri, 6(11): 29-38.

Sirait, J. 2013. Pembuatan pengering kerupuk rambak dengan kapasitas $30 \mathrm{~kg}$. Jurnal Riset Teknologi Industri, 7(14): 118-125.

Sokhansanj, S., danD. Jayas. 2007. Drying of foodstuffs. In A. Mujundar (Ed.), Handbook of industrial drying (3rd ed., pp. 522-546). Taylor dan Francis.

Suherman, S., M. Djaeni, D. H. Wardhani, M. R. Dzaki, danM. N. F. Bagas. 2018. Performance Analysis of Solar Tray Dryer for Cassava Starch. MATEC Web of Conferences, 156: 0-3.

Zarkasie, I. M., W. W. Prihandini, S. Gunawan, danH. W. Aparamarta. 2017. Pembuatan Tepung Singkong Termodifikasi Dengan Kapasitas 300.000 Ton/Tahun. Jurnal Teknik ITS, 6(2): 2-4. 